Copyright $(\subset 2018$ by the Kalmyk Scientific Center of the Russian Academy of Sciences

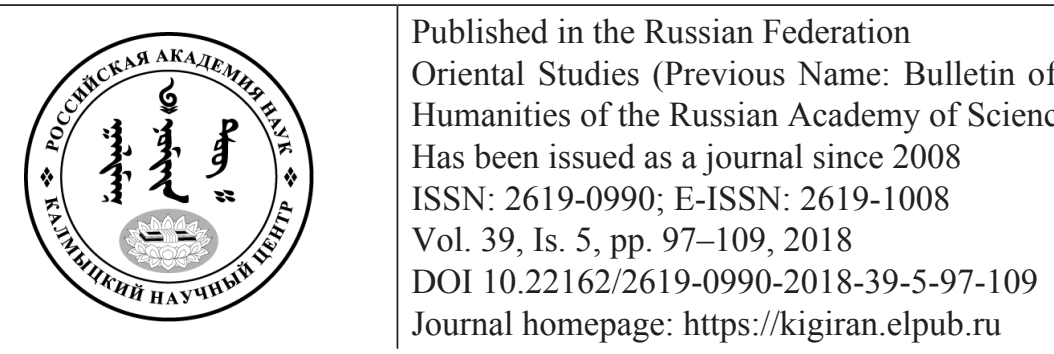

УдК 39

\title{
Шаманы и шаманки Бурятии: \\ их мистический опыт и мои экспедиционные исследования. \\ Часть 1
}

Наталия Львовна Жуковская ${ }^{1}$

${ }^{1}$ доктор исторических наук, заведующий Центром азиатских и тихоокеанских исследований, Институт этнологии и антропологии им. Н. Н. Миклухо-Маклая РАН (119991, Россия, г. Москва, Ленинский проспект, д. 32a). ORCID: 0000-0001-5415-9875. E-mail: n-zhuk@yandex. $\mathrm{ru}$

\section{Аннотация}

Цель статьи - на основе данных многолетних экспедиционных исследований дать характеристику некоторых тенденций в развитии современного шаманизма Бурятии. В работе использованы сравнительно-исторический, сравнительно-сопоставительный методы исследования; при сборе материалов, привлеченных к анализу, - методы полевой этнографической работы.

В результате проведенного исследования дана характеристика направлений развития шаманской практики в Бурятии. Автор отмечает, что характерной чертой нового поколения шаманов Бурятии является наличие у многих высшего образования, опыт работы в разных учреждениях. Произошло формирование «шаманской интеллигенции». Шаманская практика включает не только традиционные обряды, но и публичные выступления в прессе с пропагандой шаманского мировоззрения. Шаманы пишут книги, принимают участие в съемках документальных фильмов о них, выезжают из мест своего постоянного проживания в разные города России, за рубеж и там занимаются шаманской практикой, что в классическом шаманизме категорически не приветствовалось. С возникновением ассоциаций и объединений шаманов они стали заниматься издательской и просветительской деятельностью. Новые задачи потребовали изменения и личности шаманов традиционных, и поколение шаманов, востребованное новой российской действительностью, обладает такими характеристиками.

Статья включает две части. В первой части даны общая характеристика темы и портреты трех шаманок - представителей «шаманской интеллигенции»: Надежды Степановой, ЕшинХорло Цыбикжаповой и Веры Тагласовой. В их шаманском становлении прослеживаются классические черты: шаманская болезнь, наличие шаманского корня (даже в случаях межнационального брака родителей). Но новое поколение шаманок Бурятии объединяет наличие высшего гуманитарного образования, опыт работы в учреждениях образования и культуры, тесные связи с ученым миром, активная жизненная позиция, членство в шаманских ассоциациях и пропаганда шаманского мировоззрения.

Во второй части статьи дана характеристика места шаманов и шаманских объединений в новой России. Автор показывает, что возникновение шаманских объединений направлено на реализацию их практики в новых условиях, когда шаманы, организованные в сообщество, могут зарегистрировать свои священные места как особо охраняемые территории. С другой 
стороны, задача организаций шаманов - стать заслоном на пути псевдошаманов, которых в последнее время тоже появилось немало. В этой части также дается характеристика проблем «шаманы и ученые» и «шаманы и экология». Обе части статьи, публикуемые последовательно в двух номерах журнала, сопровождаются полным списком литературы.

Ключевые слова: Бурятия, шаманизм, полевая работа, шаманы, новое поколение, шаманская интеллигенция, шаманские организации, Н. Степанова, Е.-Х. Цыбикжапова, В. Тагласова

До начала перестройки в России быть шаманом в этой стране было небезопасно. Советская власть с самого начала своего существования, т. е. с 1917 г., взяла курс на поголовный атеизм всего населения, священнослужители всех религий были объявлены мошенниками, обманщиками, а в некоторых случаях и преступниками, и борьба с ними велась всеми доступными средствами. Шаманизм считался даже не религией, а чем-то еще более худшим - пережитком едва ли не первобытно-общинного строя, поэтому на долю шаманов выпало значительное количество репрессий (тюрьмы, ссылки, лишение имущества, сжигание мест шаманского культа, преследование родственников и т. д.). И тем не менее, несмотря на явную опасность этой «профессии», шаманизм и шаманы продолжали сохраняться как форма подпольной культуры у всех народов Сибири, у которых он был частью их историко-культурной традиции.

Непросто приходилось и ученым, которые хотели эту традицию изучать. Для этнографов, антропологов, культурологов она была привлекательна тем, что пронизывала собою все стороны жизни изучаемых ими народов и обладала редкой способностью выживания и самосохранения, что стало особенно ясно после начала перестройки в 1985 г. Но до ее начала существовали два типа препятствий, которые приходилось преодолевать ученым. Первый исходил со стороны местных властей, утверждавших из опасения каких-либо неприятностей для себя, что никаких шаманов и шаманизма на подведомственной им территории не существует, хотя они знали, что это не так и им поименно были известны все местные шаманы. Вторым препятствием для ученых были сами шаманы: они не доверяли ученым, приезжавшим из больших научных центров, боялись доносов с их стороны и новых репрессий, которые могли бы за этим последовать и для них самих и для тех, кто обращался к ним за помощью. Ученым при- ходилось осторожно вести себя с местной властью и одновременно постепенно завоевывать доверие шаманов и членов их семей. Относится это и ко мне, так как еще в студенческие годы я начала ездить в экспедиции в Бурятию и изучать, что представлял из себя бурятский шаманизм вообще и в то время - в частности.

Нельзя сказать, что исследования по шаманизму в России не появлялись вообще, они, конечно, были, но посвящены они были шаманизму ушедших эпох. Таковы две работы Т. М. Михайлова [Михайлов 1980; Михайлов 1987], одного из лучших специалистов по бурятскому шаманизму, который, будучи сам представителем одного из шаманских родов иркутских бурят, многое из того, что описал в своих монографиях, знал из рассказов своих предков и тайно практикующих шаманов, а также активно использовал уже к тому времени опубликованные в трех томах материалы по шаманизму первого бурятского этнографа М. Н. Хангалова, умершего в 1918 г. [Хангалов 1958-1960].

Чтобы обезопасить себя от гнева партийного начальства, Т. М. Михайлов поставил на обложке своей книги такой заголовок - «Из истории бурятского шаманизма (с древнейших времен до XVIII в.)». Его книги были настоящими глубокими исследованиями, а вот когда по приказу того же начальства шаманизм следовало крепко покритиковать, он же писал брошюры такого типа: «Бурятское шаманство и его пережитки» [Михайлов 1962] — это уже соответствовало требованиям того времени, в котором он жил, и как бы становилось ясно, что никакого шаманизма уже нет, а есть только его пережитки.

С началом возрождения религии в перестроечное и, особенно, в постперестроечное время ни обобщающих работ, ни даже конкретных региональных исследований о судьбе шаманизма в советское время тоже не появилось. Все сразу стали писать имен- 
но о процессах возрождения, что вполне объяснимо: это была живая жизнь, происходящая прямо на глазах, менявшаяся в каждый конкретный отрезок времени, и это для исследователей было гораздо более интересно. О разгроме шаманизма, репрессиях против шаманов упоминалось лишь в одном ряду с другими отрицательными явлениями времен советской власти. Но исследователи из стран Европы и США, имевшие возможность бывать в России и даже вести здесь полевые исследования, уделили внимание этому сюжету [Balzer 1999: 129134; Humphrey 1998: 373-432; Fridman 2004: 139-150], в то время как российские ученые говорили об этом как бы мимоходом, лишь в порядке констатации факта.

Тем не менее у каждого исследователя шаманизма, будь то его классические формы или современный вариант, был собственный опыт общения с шаманами в советское время. Был он и у меня. Особенно удачным я его назвать не могу, ибо на нем отразился отблеск того времени, в какое это общение происходило. Но и оно позволяет сделать некоторые обобщения.

В 1959 г. студенткой кафедры этнографии Московского государственного университета я впервые приехала в Бурятию и начала здесь свою исследовательскую работу, которая продолжается по сию пору. Объектом моего исследования стал Тункинский район, где, как я знала, удачно переплелись шаманизм, буддизм и православие, и даже сохранился осколок языческих времен - культ гор. Я знала, что в районе есть несколько шаманов, осторожно искала возможность с ними встретиться, иногда это удавалось, но чаще они старались от этих встреч уклониться.

Весь шаманский набор обрядов в это сложное время переместился из дневного времени, что было правилом, в ночное, что считалось нарушением правил - шаманские духи более охотно откликались на призыв шамана прийти на помощь при свете дня и не любили это делать в темноте. Кроме того, при проведении обряда ночью в некотором отдалении от места действия выставляли охрану из молодежи, которая должна была с помощью условных знаков (свиста, крика птиц или животных) предупредить о появлении поблизости нежелательных лиц. Возможно, так было не везде, но ныне покойная жительница села Кы- рен, Дарья Танхаева, в молодости жившая в Торской степи, говорила мне, что в возрасте 15-17 лет ее часто ставили в караул, когда шаманил ее дядя; сейчас ей смешно об этом вспоминать, но тогда она страшно боялась.

Таким образом, шаманская традиция в советское время продолжала сохраняться в тайной форме, шаманы редко популяризировали свою деятельность, их клиенты тоже хранили молчание, опасаясь и властей, и научных работников - исследователей религиозной ситуации на местах, и даже просто не в меру любопытных людей. Так создалось впечатление, что советская власть сумела одолеть шаманизм и что он практически самоликвидировался примерно к 60-м гг. ХХ в. К счастью, это оказалось не так. Шаманская традиция пережила советскую власть и на волне общего возрождения традиционных культур и религий, начавшегося в России с конца 80-х гг., стала быстро набирать силу [Жуковская 2000: 157-158; Жуковская 2008; Zhukovskaya 2009).

Постсоветское время и пространство явило научному миру и миру вообще яркий всплеск возрождения самых разнообразных религий - от мировых (христианства, ислама, буддизма и их национальных форм) до узколокальных языческих культов, порою даже одного села или района, никому не известных. Промежуточное место между ними занимает шаманизм.

Возрождение шаманизма породило огромную волну научных исследований этого процесса, сопровождавшегося отнюдь не научными, часто полуграмотными публикациями в газетах и журналах, которые основательно запутали картину происходящих явлений. Анализ публикаций за эти годы позволил ученым прийти к выводу о неоднородности процессов, идущих в шаманском мире. Наиболее яркое из таких исследований - книга В. И. Харитоновой «Феникс из пепла? Сибирский шаманизм на рубеже тысячелетий» [Харитонова 2006]. Понятие возрождение шаманизма включило в себя ряд явлений, существующих вполне самостоятельно, но объединенных термином шаманизм только потому, что он широко известен и понятен многим, кого интересует всякого рода эзотерика.

Действительно, восстанавливались традиционные места шаманского культа (священные горы, перевалы, рощи, родовые 
захоронения и др.), разрушенные или преданные забвению в советское время, шаманы начали выполнять необходимые обряды, но в то же время шло создание ассоциаций, объединений, союзов шаманов внутри этнически относительно однородных регионов.

Возникновение шаманских ассоциаций - это явный отход от классического шаманизма былых времен, в которые ценилась индивидуальность, а вовсе не коллегиальность в подобных делах.

Вышедший из подполья, в котором он находился с 20-х по 80-е гг. ХХ в., шаманизм громко заявил о себе в самых разнообразных сферах. Шаманы стали уже не только совершать обряды, что от них требовалось всегда, они стали публично выступать в прессе с пропагандой шаманского мировоззрения, издавать свои книги [Ангараева 1996, 1997, 2002; Базаров 1999, 2000, 2009; Гомбоев 2010], охотно позволять снимать о себе документальное кино, выезжать из мест своего постоянного проживания в столичные города России, а затем и за рубеж в Европу, Америку, азиатские страны - и там делать то, что в классическом шаманизме категорически не приветствовалось: на чужой территории вдали от своих духовпомощников (они же часто духи предков), оставшихся на родине шамана, проводить какие-либо шаманские действия, кого-либо лечить, а то и просто без повода демонстрировать свои экстрасенсорные способности и самим назначать за это какую-то плату.

В рамках возникших ассоциаций и объединений шаманы начали заниматься издательской и просветительской деятельностью, что, вообще-то говоря, уже никак с шаманизмом как видом религиозной деятельности не связано. Но зато связано с шаманизмом как видом знания — религиозного, мировоззренческого, практического, природного - все зависит от того, кто как воспринимает шаманизм. Сюда относятся несколько раз переизданные карты священных мест Бурятии и теперь уже ежегодно издаваемые календари с указанием дат, когда нужно проводить шаманские обряды почитания духов родовых и семейных предков там, где находятся места их почитания. Разумеется, с такими задачами шаманы традиционного образца справиться бы не смогли. Но зато эта задача оказалась под силу новому поколению шаманов, востребованному новой российской действительностью.

\section{Появление шаманской интеллигенции}

Появившееся в последние три десятилетия в Бурятии поколение шаманов - не всех, разумеется, но некоторых - можно назвать шаманской интеллигенцией. Понимая некоторую условность этого понятия, объясняю, что я имею в виду. Прежде всего, это молодая генерация шаманов - не по физическому возрасту (многим из них далеко за 40 лет и выше), а по призванности к выполнению шаманского долга в относительно недавнее время. Для этого поколения характерно наличие высшего светского образования, работа в различных светских учреждениях — вузах, школах, библиотеках, административном аппарате, что отлично совмещается с выполнением ими шаманских функций. Как оказалось, можно делать светскую карьеру, принадлежать к категории республиканской интеллигенции и в то же время быть шаманом и при этом не испытывать идеологического и производственного дискомфорта. В качестве особо интересного примера такого совмещения может служить биография умершего в 1996 г. Юрия Хараева, заслуженного деятеля культуры Республики Бурятия, почти четверть века проработавшего в Национальной библиотеке Республики Бурятия в качестве ее директора. Он же был известным шаманом, и его клиентуру составляли не только его сородичи, но и сотрудники аппарата Правительства Бурятии, высшая техническая и художественная интеллигенция республики. Бывшие клиенты и «коллеги» по шаманской профессии вспоминают его с большой теплотой и уважением. Несомненно, что он один из ярких представителей бурятской интеллигенции в целом и столь же яркий представитель шаманской интеллигенции, в частности. После его смерти главный печатный орган Правительства Бурятии, газета «Правда Бурятии», опубликовала некролог, в котором были перечислены все его светские заслуги и должности, и в одном ряду с ними упоминалось, что он был и шаманом тоже. Под некрологом стояли подписи самых высоких лиц республики. Это был первый случай публичного признания заслуг представителя интеллигенции в качестве шамана.

Особо теплые отношения в этот период сложились у меня с тремя бурятскими шаманками. С каждой из них я встречалась много раз за время экспедиционной работы 
в Бурятии, которая продолжалась с 1991 по 2010 гг. Первая в этом списке - Надежда Степанова, родом из Кижингинского района, куда ее предки после землетрясения 1862 г. переселились из Кабанского района Бурятии. Ей около 70 лет. Ее знают не только в Бурятии, но и за ее пределами. Она - создательница и первый Президент Общества шаманов Бурятии. В 2000 г. Н. Степанова стала Президентом Общества центрально-азиатского шаманизма. Одновременно она — член Межрелигиозного Международного комитета при ЮНЕСКО. Как и многие современные шаманы, Н. Степанова имеет высшее образование. Окончила библиотечный факультет Института культуры в Улан-Удэ (ныне Восточно-Сибирский государственный институт культуры и искусства - ВСГИК). Некоторое время работала в школе. Уже став шаманкой, работала во ВСГИК, преподавала на кафедре этнологии и фольклора «Основы шаманской практики». О том, как осознала себя обладателем особого шаманского дара, рассказывает охотно. С детства она обладала способностью «видеть» (то, что не видят другие) и «слышать» (какие-то голоса, которые не слышат другие), хотя тогда не осознавала, что это какое-то особое свойство, думала, что все так умеют. Однако это понимала ее мать, знавшая шаманскую генеалогию их рода, и пыталась ее от этого избавить, ездила к шаманам. Тем удавалось ненадолго избавить ее от «голосов» и «видений», но через некоторое время они вновь возвращались. Ее судьба шаманки определилась уже в достаточно зрелом возрасте. Плохо себя чувствовала, ее одолевали голоса и видения, неожиданно без всяких видимых причин скоропостижно умер муж, начали болеть дети. Она по-прежнему не сдавалась и не желала брать на себя бремя шаманского служения. Все решилось в один момент, когда некий виртуальный голос возвестил ей, что на другой день ее насмерть собьет грузовик. В тот же день она приняла решение взвалить на себя этот груз. Ее учителем стал Борбоев Леонтий Абзаевич (шаман, имеющий 9 посвящений), от него она получила первое и последующие посвящения. Практически ей доступен весь (или почти весь) спектр шаманских обрядов. Обладает способностями телепатии, ясновидения, хилерства.

Н. Степановой принадлежит инициатива создания в 1993 г. Общества шама- нов Бурятии «Хэсэ Хэнгэрэг» - дословно переводится 'Грохочущий бубен' (с 1999 г. оно называется «Бөө мүргэл» 'Шаманская вера'). В сложное перестроечное время, когда Республика Бурятия, как и большинство регионов России, бурлила политически и деградировала экономически, она предложила шаманам Бурятии провести серию тайлаганов в честь 5 главных божеств-покровителей бурятского народа (за несколько лет это было сделано), а потом стала активным пропагандистом и защитником (от ярых атеистов и чересчур активных буддистов) шаманского мировоззрения и практики. Резко выступает против неошамановшарлатанов. Однажды Н. Степанова попала в поле зрения итальянского кинодокументалиста К. Алеоне, снявшего о ней фильм, который произвел большое впечатление в Италии. Ее пригласили туда приехать. С тех пор она побывала во многих странах Европы, в США. В Италии и Франции она создала школы обучения шаманской практике. Лояльна ко всем религиям, не раз бывала делегатом международных съездов представителей разных конфессий. Участвует в научных конференциях, конгрессах в России и за рубежом, публикует статьи. О ней написана книга - точнее, она надиктовала рассказы о своей жизни, их перевели и издали в Италии [Stepanova 1998]. О ней пишут бурятские газеты, она охотно выступает по местному TB, участвует в разных презентациях, фестивалях, праздниках, где наряду с Хамбо-ламой Бурятии и Благочинным Забайкальского округа Читинской епархии благословляет участников очередного мероприятия. Как практикующая шаманка Н. Степанова активно откликается на просьбы всех нуждающихся в ее помощи, выезжает на обряды и в черте города, и в районы.

Всемирная академия Чингисхана, профессором которой Н. Степанова является, присвоила ей звание Дуурисха удаган ('Верховная шаманка'). Она член Координационного совета шаманов мира (Германия), выступает с лекциями в разных странах Франции, Италии, Бразилии, проводит семинары по шаманской практике в Греции, Австрии, Перу.

Мне приходилось давать с Н. Степановой совместное интервью в защиту острова Ольхон - сакрального центра бурятского народа. Приходилось встречаться с нею и на конференциях, хотя наука - не главное 
в ее деятельности, каждый раз это было посвоему интересно.

В июле 2000 г. в Улан-Удэ проходила международная конференция «Проблемы истории и культуры кочевых цивилизаций Центральной Азии». Совместно с Т. М. Михайловым я вела секцию «Традиционная культура народов Южной Сибири». Это была мирная этнографическая секция, ничто не предвещало каких-то осложнений. Неожиданно после доклада хакасского шамана Валерия Топоева и демонстрации им способов лечения, используемых в практике хакасских целителей, с места буквально подскочил бурятский шаман Баиров, обозвал В. Топоева шарлатаном, заявил, что его лечение неправильное и вообще это «не лечение». Он предложил свои способы, пытаясь поднять кого-либо из сидящих в зале и продемонстрировать свои таланты на их примере. Над залом нависло некое серое облако страха, люди старались не смотреть друг на друга и на разъяренного Баирова в особенности. Ситуация была не из приятных. Я как ведущая заседание растерялась и не очень представляла, как можно урезонить разгневанного шамана.

Помощь пришла неожиданно в лице Н. Степановой, тихо сидевшей до этого в дальнем углу зала. Она попросила слова и за несколько минут сняла напряжение, сказав примерно следующее: шаманизм у народов Сибири, конечно, общее явление, имеет одни и те же истоки в древних обычаях, но все же у каждого народа он чем-то отличается, а потому и практика лечения и проведения обрядов разная, это не означает, что у кого-то она плохая, а у кого-то хорошая, просто она разная.

Все успокоились, лица у присутствующих посветлели, к тому же прозвенел звонок на обед, и все, оживленно переговариваясь и обсуждая случившееся, двинулись в столовую. Конечно, я оценила протянутую мне руку помощи и миротворческую акцию Н. Степановой. Периодически при наших встречах я вспоминаю этот эпизод, однако она оценивает его иначе: «Я никому не помогала, - говорит она, — я просто сказала, что есть на самом деле». С учетом достигнутого эффекта это особенно ценно.

На конференции в Тунке в 2004 г. мы снова оказались вместе. На сей раз в программе конференции был объявлен доклад Н. Степановой «О единстве природы шаманской силы (из опыта общения с шама- нами разных народов мира)». Она говорила, в общем-то, о том же самом, что и четыре года назад, только расширив географические рамки своего выступления от Южной Сибири до масштабов всего остального мира, который сумела основательно объездить за последние 10 лет. Она познакомилась с шаманами многих стран, где шаманизм под иным названием и с иным обрядовым набором, но с той же функциональной ролью в системе культуры существует и поныне, нисколько не противореча ни политическим, ни идеологическим установкам этих стран. Н. Степанова говорила об этом легко, свободно, переходя с русского языка на бурятский и обратно, не пользуясь никакими записями, и чувствовалось, что выступления на трибуне уже стали такой же естественной гранью ее личности, как и профессиональные шаманские обязанности, которые по-прежнему остаются основным делом ее жизни.

Вторая представительница шаманского мира Бурятии, с которой я с большим удовольствием встретилась в Тунке, это Цыбикжапова Ешин-Хорло. Я познакомилась с нею в 1998 г. в Москве, куда она приехала в командировку по делам БИПКРО (Бурятского института повышения квалификации работников образования), где она в тот момент работала, и одновременно по приглашению одной семьи, живущей в Москве, где был тяжелый больной, которому она взялась оказать помощь. За эффективностью ее лечебной деятельности в тот период наблюдала корреспондент газеты «Российская медицина», врач по основной специальности Г. П. Князева, которая впоследствии опубликовала о Е.-Х. Цыбикжаповой в этой газете большой материал.

Когда мы познакомились с Ешин-Хорло поближе, она рассказала о себе следующее. Родилась в 1952 г. в Кижингинском районе Бурятии, в ее семье шаманский дар «разделился» между тремя родными сестрами, у каждой из которых он проявил себя посвоему: одна из сестер владеет даром мануальной терапии, вторая лечит энергетикой своего биополя, сама Ешин-Хорло обладает даром пения, имеющего терапевтический характер. Дар этот пробудился в ней в конце 1980-х годов. В 1987 г. она получила первое посвящение. Как многие современные шаманы, она имеет высшее образование: окончила педагогический факультет Института культуры (ВСГАКИ). Работала лекто- 
ром районо, затем сотрудником БИПКРО. С 1999 г. она - практикующая шаманка.

В 2000 г. ей предложили работу в школе-интернате для детей с психическими отклонениями в Новосибирске. Она приняла это предложение, но через пару лет открыла собственные курсы по самоусовершенствованию физической и психической природы человеческой личности - именно так она определила характер своей нынешней деятельности. Основными ее клиентами были молодые и средних лет женщины, которым необходимо восстановить веру в свои силы и возможности. Цикл психофизических упражнений для них она разработала сама. Выполняя эти упражнения, человек должен избавиться от находящихся в нем «отрицательных сущностей» (их много, и они поразному выглядят) и добиться того, чтобы им на смену пришли «положительные сущности». Тогда внутренняя природа человека очищается, он освобождается от всего ему ненужного, его лицо и тело разглаживаются, душа успокаивается, он молодеет, а главное - становится свободным. Именно в этом основная цель ее методики.

Лучшая реклама этой методики - сама Ешин-Хорло. Ей уже больше 60 лет, а выглядит она на 35 . Эти изменения произошли с ней уже после того, как мы познакомились в 1998 г. Все свои методики она отшлифовала на самой себе и теперь говорит о себе: «Я свободна, мне все доступно, я все могу, мне никто не нужен, я ни от кого не завишу; я хочу помочь всем, кто желает достичь этого состояния». Так она рассказывала мне о своей нынешней деятельности, пока мы общались во время конференции.

Любопытно добавить следующее: если в момент первого знакомства она представилась как шаманка, то сейчас это слово по отношению к себе не употребляет, считает, что теперь оно не соответствует ее сущности. «Ну, а какое соответствует?» - спрашиваю я. Некоторое время она размышляет, потом говорит: «Психолог». Это для нее уже более высокая степень оценки собственной личности. Тем более, что она окончила заочное отделение психологического факультета Новосибирского университета.

Однако для меня главным ее талантом остается тот, которым она удивила меня в год первого знакомства - это дар терапевтического пения. Ешин-Хорло каждого человека воспринимает в виде мелодии, часто сопровождающейся словами несуществу- ющего языка; фонетически он напоминает один из реальных языков (монгольский, японский, русский, итальянский); мелодия же соотносима с определенной культурой. Почему конкретного человека она «пропевает» в виде той или иной мелодии, она объяснить не может, говорит лишь, что эта мелодия приходит сама. Что за слова она произносит - тоже не объясняет: она их содержание не понимает, они тоже приходят извне. В ходе такого пения происходит лечение человека. При необходимости через некоторое время сеанс пения повторяется, в некоторых случаях, наверное, не раз. Любопытно, что хотя тип мелодии, связанный с конкретным человеком, сохраняется при повторном сеансе, сама мелодия все-таки имеет отличия. Ешин-Хорло объясняет это тем, что в человеке постоянно происходят какие-то изменения и сегодня он не такой, как вчера, а завтра будет не таким, как сегодня.

Перед началом сеанса пения ЕшинХорло интересуется некоторым набором данных о человеке (национальность, место рождения, возраст), но более всего - его вероисповеданием. По ее словам, ей неважно, является ли ее клиент буддистом, мусульманином, христианином или кем-либо еще; ей важно знать, в какой культурной традиции он вырос, какие боги или духи являются его покровителями. Они становятся ее духами-помощниками, к ним она обращается за помощью, когда начинает петь (=лечить) человека. По окончании сеанса она в изнеможении опускается на стул, с ее лица струится пот. Она долго приходит в себя - форма выхода из состояния транса. Ешин-Хорло может петь (=лечить) клиента в его отсутствие, пользуясь услугами медиатора (человека, близкого заболевшему).

Самым интересным и загадочным в подобном сеансе лечения, как мне кажется, является тип мелодии: почему она именно такая, а не другая. Впрочем, иногда оказывалось, что объяснение найти можно с помощью самого клиента (=больного). Однажды Ешин-Хорло пришлось лечить от пневмонии человека, которого она никогда не видела, ничего о нем не знала, и имени его тоже. Сеанс лечения проходил в квартире заболевшего, который в это время лежал в больнице; в качестве посредника между отсутствующим больным и Ешин-Хорло выступала жена больного. Получив от жены необходимую ей информацию о больном 
(национальность - армянин, вероисповедание - армянская апостольская церковь, и весьма условное описание того, как выглядит храм приверженцев этой религии, в котором больного крестили), она «запела» отнюдь не армянскую, а очень легко опознаваемую итальянскую мелодию со словами, очень похожими на итальянские. Как выяснилось впоследствии, прабабка клиента была итальянкой, а, значит, в нем имелась «осьмушка» $(1 / 8)$ итальянской крови. Именно она с точки зрения того «виртуального терапевта», который через душу, тело и голос Ешин-Хорло выступает в качестве лечащего начала, стала отправной точкой сеанса лечения.

В мою личную жизнь Ешин-Хорло внесла один пикантный момент. Несколько раз по разным поводам (лечебным и просто так) она «пела» меня и каждый раз немного поразному, но всякий раз это была протяжная монгольская песня (уртын дуу — 'протяжная песня', особый лирический песенный жанр), я не раз слышала такие песни в Монголии. Слов, как всегда, было не разобрать, но ни малейшего сомнения, что это именно уртын дуу, у меня не было. Не скрою, приятно было сознавать, что тебя воспринимают в виде такой красивой мелодии, но все же это вызывало недоумение: почему меня, русскую женщину, Ешин-Хорло воспринимает в виде монгольской протяжной песни. Я задала ей этот вопрос. С некоторым недоумением она ответила: «Но Вы же в прошлом перерождении были монголкой!» Этот ответ мгновенно разъяснил все «непонятности» моей жизни. До этого я никогда коротко и ясно не могла объяснить, почему посвятила свою жизнь изучению культуры монгольского кочевого мира. И вот теперь у меня есть короткий и ясный ответ на этот вопрос.

Завершая портрет Ешин-Хорло, добавлю еще некоторые дополнительные детали: она общительна, активна, любит в меру выпить; если «поет» при исполнении шаманских обязанностей, голос потрясающий, диапазон и сила огромные (низкий, высокий, глубокий - все зависит от музыкального портрета клиента). Когда поет просто так, во время дружеского застолья, нет ни голоса, ни слуха. «Подмосковные вечера», которые она пела однажды в обычной компании у меня в квартире, невозможно было слушать. Впрочем, допускаю, что это была «игра», желание показать «а вот я и так могу». Когда-то Ешин-Хорло была замужем (муж умер более 30 лет назад), есть две дочери и сын, у каждого из них своя семья, свои сложности, своя жизнь. Она старается в их дела не вмешиваться, но если попросят о помощи, то помогает. Склонность к философскому осмыслению природы, человека, культуры вызвала потребность как-то самовыразиться и написать книгу. И написала, назвав ее «Космическая эволюция в героическом эпосе «Гэсэр» [Цыбикжапова 1998].

На конференции в Тунке Ешин-Хорло не выступала ни с докладами, ни с сообщениями, ни с какими-либо комментариями по поводу того, что говорили ученые. Она нашла себе другое занятие. На конференцию съехались шаманы разных районов, многие прежде не знали друг друга. Начались знакомства, взаимное «прощупывание» возможностей каждого, образовались своего рода биоэнергетические тандемы по оказанию услуг как участникам конференции, так и местным жителям, которые быстро среагировали на появление у них в районе столь значительного контингента лечащих шаманов. В одном таком деле мне пришлось выступить не только посредником, но и инициатором.

Моя давняя подруга Людмила Шубина, заслуженный учитель Республики Бурятия, жившая в пос. Кырен, давно жаловалась на алкогольное увлечение сына, которое сделало жизнь его семьи (у него жена и дочь) и жизнь родителей совершенно невыносимой. Я спросила Ешин-Хорло, не возьмется ли она помочь. Ешин-Хорло ответила: при одном условии - сын сам должен этого желать и добровольно согласиться на обряд. Но именно этого добиться не удалось: сын, русский по национальности, атеист по убеждениям, наотрез отказался совершать над собой какой-либо шаманский обряд, тем более, что считал себя не алкоголиком, а просто ежедневно выпивающим по причине разного рода тягот в жизни. Ешин-Хорло заявила, что ничего не получится. Но некоторое время спустя она посоветовалась с Туяной Дашиевой (ясновидящая из пос. Петровский Читинской области, тоже участница нашей конференции), с которой у нее сложился тот самый биоэнергетический тандем, и они решили провести обряд сообща в отсутствие упрямого сына. Проводили его на улице, на мосту через реку Кыренка, не обращая внимания на любопытствующих прохожих. Ешин-Хорло «пела», стоя 
лицом к лицу с Людмилой, и ее пение было боле всего похоже на рев раненого зверя, а ясновидящая Туяна стояла, прижавшись к спине Людмилы, объясняя свою позу тем, что так она лучше «видит» результаты проводимого обряда. По окончании они сказали, что положительного исхода не гарантируют, так как душа сына окружена прочной броней нежелания менять что-либо в своей жизни, нужен прямой контакт с ним. Но есть один момент, который может изменить ситуацию - это сердце матери; только через него возможны какие-то сдвиги в сознании детей. Этот канал начнет действовать только тогда, когда сын трижды прикоснется к сердцу матери.

В тот же вечер сын (он живет отдельно) зашел в гости к матери. Он был трезвым, что в последние годы случалось редко. «Сыночек, - попросила Людмила, - положи мне руку вот сюда», и она указала на сердце. Сначала такое предложение вызвало у него явное отторжение, но увидев умоляющий взгляд матери, он подошел к ней, она обняла его, и первый контакт его руки с сердцем матери состоялся. Однако, увидев повеселевшее лицо матери, сын что-то заподозрил и сразу же отошел.

Вечером мы обсуждали с Людмилой, как «спровоцировать» сына сделать то же самое еще дважды. Второй раз он на ту же приманку уже не клюнет. Так ничего и не придумали. Через 3 дня я вернулась из Кырена в Улан-Удэ, а еще через 10 дней я уже была в Москве. Из Москвы позвонила узнать, как дела у сына. Услышала, что уже две недели не пьет и никто вокруг не может поверить в такое счастье. А позвонив через 3 месяца, узнала, что пьет по-прежнему, и его жена, забрав дочку, в очередной раз ушла к родителям. Может быть, два других прикосновения к сердцу матери так и не состоялись, но, скорее всего, надо очень захотеть самому избавиться от своего недуга, приносящего несчастье близким. Тогда не столько шаман тебе поможет, сколько ты сам поможешь себе. Кстати, кодирование точек мозга, регулирующих потребление алкоголя, не такая уж трудная для шамана задача. Вот только редко кто обращается к ним с такой просьбой.

Третья шаманка из числа моих старых знакомых, приехавших на конференцию, это Тагласова Вера. Она не была участницей конференции: докладов не делала, в обрядах не участвовала и вообще приехала как частное лицо. На конференцию ее никто не пригласил, хотя в феврале 2004 г. она стала председателем Общества шаманов Бурятии «Бөө мүргэл», сменив на этом посту Н. Степанову. Вера была обижена таким невниманием к ней, хотя, скорее всего, в этом не было злого умысла: обычная организационная неразбериха, неясность, кто за что отвечает и кто кого приглашает. И так как «Бөө мүргэл» входила в число устроителей конференции, то, в конце концов, В. Тагласова как ее председатель пригласила себя сама, сама приехала и поселилась у собственной дочери, которая уже год жила в Кырене. Она знакомилась с местными и приезжими шаманами, ей как председателю Общества это было важно. Так получилось, что с Ешин-Хорло ее познакомила я, и они очень понравились друг другу. Мне это тоже было приятно.

Биография Тагласовой очень интересная: в чем-то типичная для становления шамана, в чем-то весьма нестандартная. Родилась в 1959 г. в Иркутской области. Мать - русская, отец - бурят из рода хогой, входящего в состав булагатов. Имеет шаманских предков по линии отца. Отец ушел от матери, когда Вере было всего 3 года; она росла в русской семье и совершенно не знала бурятского языка. Бабушка по линии матери была народной целительницей и часто говорила Вере, когда та еще была девочкой: смотри, как я лечу, какие травы использую, запоминай, какие заговоры я произношу. Та отнекивалась, говорила, что если заболеет, то врачи вылечат; теперь, став шаманкойврачевательницей, очень об этом жалеет. В 18 лет вышла замуж, родила дочь. В 20-21 год у нее началась шаманская болезнь, хотя ни она, ни ее окружение этого не понимали. Болезнь была непонятная: ничто не болело, но она теряла силы, вскоре уже не могла ходить. В таком состоянии пробыла 6 лет, муж от нее ушел, жила со своей матерью. Откровение о том, что она избранница духов, пришло от двух стариков бурят, увидевших одновременно практически одинаковый сон на эту тему и сообщивших об этом ее матери. Та им сначала не поверила, но так как Вере стало совсем плохо, смирилась и отвезла дочь к родственникам отца. Там ее уже ждали. Становление ее как шаманки стало происходить довольно быстро. Сама собой прошла болезнь. Бурятский язык она быстро выучила на бытовом уровне, а в момент первого посвящения обрела са- 
кральный язык общения с духами. Обладает сильным даром ясновидения; как целительница особенно сильна в женских и детских болезнях, патологиях беременности и родов. Прошла 3 посвящения. Сама выбирает дерево и животное, из кожи которого ей после очередного посвящения делают новый бубен.

Живет постоянно в Улан-Удэ, часто выезжает на обряды в район, особенно в Иркутскую область, откуда она родом. Пациентов принимает не в своей городской квартире, а в специально купленной для этих целей квартире в пригороде. Считает своей нормой работы с клиентами - 6-7 человек в день, предпочитает первую половину дня. Для проведения обряда просит приносить с собой чай, молоко, печенье, конфеты. Водку не использует. Вторично замужем, от первого брака имеет дочь.

В. Тагласова в 1996 г. окончила тот же самый вуз, что и Н. Степанова, и Е.-Х. Цыбикжапова - Восточно-Сибирскую государственную академию культуры и искусств в Улан-Удэ, специализировалась при кафедре этнологии и фольклора. Писала дипломную работу о шаманизме на основе архивных материалов, хранящихся в Отделе письменных памятников Института монголоведения, буддологии и тибетологии CO РАН (ныне Центр восточных рукописей и ксилографов - ЦВРК ИМБиТ СО РАН). Учившиеся с ней в одной группе Б. Гомбоев и С. Болхосоев стали учеными-шамановедами, оба уже защитили кандидатские диссертации, она поддерживает с ними личные контакты, они обращаются к ней как к шаманке за помощью в разных критических ситуациях в своей жизни (поступление в аспирантуру, защита диссертации и т. п.).

С Верой Тагласовой связано одно важное событие в моей жизни. Подходила к концу моя очередная «рабочая» встреча с нею, в которой я выступала не клиентом, а ученым, задававшим ей разные вопросы про ее шаманскую деятельность, а она отвечала на них как обычный информатор, ничего мне специально не демонстрируя. Когда наш разговор подошел к концу, и я собралась уходить, она внезапно сказала следующее: «Вас пригласят в далекую восточную страну, пригласит очень высокое лицо, вас будет смущать это приглашение, но не отказывайтесь, вы получите такое удовольствие, которое останется с вами на всю жизнь». Это предсказание было сдела- но в августе 2000 г., и я, честно говоря, не очень ему поверила, так как не поняла, кто и куда должен меня пригласить. А через четыре месяца, накануне наступления Нового 2001 года, мне позвонил глава буддистов Бурятии Пандито-Хамбо-лама Дамба Аюшеев и предложил мне войти в состав делегации бурятских буддистов, которая по приглашению Далай-ламы XIV поедет в его резиденцию г. Дхарамсалу (Индия, штат Химачал Прадеш) для того, чтобы ему, в свою очередь. вручить приглашение приехать к его последователям в Бурятию с целью освятить новые построенные буддийские храмы, дать учение и посвящение в буддисты всем желающим его принять.

Конечно, я согласилась, немало удивившись тому, как быстро и точно исполнилось предсказание Веры. Далекая восточная страна - это Индия, высокое пригласившее меня лицо - это Далай-лама XIV. Немного смутил меня состав делегации — 10 буддийских монахов и я, единственная женщина среди них и вовсе не монахиня, но так как монахи относились ко мне как к ученой даме весьма почтительно, то смущение я быстро преодолела. И, конечно, вся эта поездка - прием у Далай-ламы, его неподдельный интерес ко всем нам и ко мне, в частности, как единственной женщине в нашей группе, к тому же представительнице мира науки - конечно, это все останется со мною и во мне на всю жизнь.

Хотелось бы сказать несколько слов о трех монгольских шаманках, которые приехали на тункинскую конференцию из Монголии отнюдь не для зачитывания или прослушивания докладов, а для участия в одном единственном обряде, жертвоприношении духу-хозяину Байкала. Их звали Сувд, Загдаа и Мөнхө. Они привезли с собой полную шаманскую экипировку: шаманский костюм, головной убор, сапоги и огромные роскошные бубны. Всех участников конференции в последний день привезли на мыс Шаманский, что на южном берегу Байкала, и каждая из них по очереди совершила свой собственный обряд в честь Байкала, сопровождая его попутно очищением и лечением тех, кто в этом нуждался, и умиротворением всех окрестных духов. Сделать коллективный обряд, как планировалось ранее, не удалось, так как вершина холма, на котором все происходило, не позволяла по своим размерам «работать» одновременно более чем одному шаману, особенно когда у того начиналась заключительная фаза камлания. 
Bсе было бы прекрасно, если бы не туристы. Накануне по всем турбазам южного и юго-западного побережья Байкала было объявлено о том, что состоится шаманский обряд, и скучающие российские и иностранные (корейские, китайские и западноевропейские) туристы, вооруженные до зубов всякой фото- и киноаппаратурой, облепили мыс Шаманский и, несмотря на все запреты, норовили влезть в тот самый узкий круг, где бились в экстазе шаманки, и обязательно сфотографироваться рядом с ними и даже прикоснуться к ним. Все попытки урезонить их успеха не имели, так как у туристов своя ментальность, голосу разума и сакральным предостережениям не подвластная. Длилось все это около 5 часов. Именно о таком привлечении туристов и о таком использовании шаманов для поднятия своих доходов мечтает администрация национального парка «Тункинский». И у них уже в этом есть помощники - журнал «Открытый Мир Asia», полностью ориентированный на туристов в Байкальском регионе, Центр путешествий и приключений «В мире фантазий», разместившийся на курорте Аршан в Тункинской долине и неплохо эксплуатирующий шаманскую тематику.

Увы! Шаманизм в наши дни все более становится частью шоу-бизнеса, особенно в регионах развивающегося туризма. Сами шаманы относятся к этому по-разному: одни не замечают этого и делают то, что считают своим долгом, другие все видят и стараются уклониться от ненужной публичности и показухи, третьи считают, что это нормально, что шаман вполне может развлекать туристов, тем более, что это хорошо оплачивается, а кому не нужны деньги в нашей весьма непростой жизни. К сожалению, последняя категория растет очень быстро, пополняя свои ряды не только за счет псевдошаманов, чующих легкую наживу, но и настоящих шаманов. Последние не очень ориентируются в тенденциях нынешнего времени и могут попасть в ловушку, которую оно расставляет хранителям национальных традиций.

Таким образом, шаманская интеллигенция - новое явление, порожденное новой Россией и ее социальными реформами.

Во второй части статьи, планирующейся к публикации в следующем номере журнала, будут рассмотрены другие вопросы, связанные с положением шаманов и шаманок Бурятии в новой России.

\section{ЛИТЕРАТУРА / REFERENCES}

Ангараева 1996 - Ангараева Н. В. Время огня. Улан-Удэ: [б.и.], 1996. 24 c. [Angaraeva N. V. Vremya ognya [Time of Fire]. Ulan-Ude, 1996. 24 p. (In Rus.)]

Ангараева 1997 - Ангараева Н. В. Веточка вербы с бубенцами. Улан-Удэ: [б.и.], 1997. 35 с. [Angaraeva N. V. Vetochka verby s bubentsami [A Willow Twig with Small Bells]. Ulan-Ude, 1997. 35 p. (In Rus.)]

Ангараева 2002 - Ангараева Н. В. (Наёхан). Красота бескорыстной любви. Улан-Удэ: AOA Респ. тип. РБ, 2002. 95 с. [Angaraeva N. V. (Naekhan). Krasota beskorystnoy lyubvi [The Beauty of Unconditional Love]. UlanUde: Buryatia Republ. Press, 2002. 95 p. (In Rus.)]

Базаров 1999 - Базаров Б. Д. Таинства и практика шаманизма. Кн. 1. Улан-Удэ: Буряад унэн, 1999. 236 с. [Bazarov B. D. Tainstva $i$ praktika shamanizma [Mysteries and practices of shamanism]. Book 1. Ulan-Ude: Buryaad Unen, 1999. 236 p. (In Rus.)]

Базаров $2000-$ Базаров Б. Д. Таинства и практика шаманизма. Кн. 2. Улан-Удэ: Буряад унэн, 2000. 202 c. [Bazarov B. D. Tainstva $i$ praktika shamanizma [Mysteries and practices of shamanism]. Book 2. Ulan-Ude: Buryaad Unen, 2000. 202 p. (In Rus.)]

Базаров 2009 - Базаров Б. Д. Таинства и практика шаманизма. Улан-Удэ: Изд-во Бурятского госуниверситета, 2009. 208 c. [Bazarov B. D. Tainstva i praktika shamanizma [Mysteries and practices of shamanism]. Ulan-Ude: Buryat State Univ., 2009. 208 p. (In Rus.)]

Гомбоев 2010 - Гомбоев С. Ж. Под Вечным Синим Небом. Святая неугасимая вера. Шаманизм. Улан-Удэ: Тип. НовоПринт, 2010. 334 c. [Gomboev S. Zh. Pod Vechnym Sinim Nebom. Svyataya neugasimaya vera. Shamanizm [Under the Eternal Blue Sky. Shamanism: a holy never-to-fade faith]. UlanUde: NovoPrint, 2010. 334 p. (In Rus.)]

Жуковская 2008 - Жуковская Н. Л. Буддизм и шаманизм как факторы формирования бурятского менталитета // Религия в истории и культуре монголоязычных народов России. М.: Вост. лит., 2008. С. 9-36. [Zhukovskaya N. L. Buddhism and shamanism as factors to delineate the Buryat mentality. Religiya v istorii $i$ kul'ture mongoloyazychnykh narodov Rossii [Mongolic peoples of Russia: religion in their history and culture]. Moscow: Vost. Lit., 2008. Pp. 9-36. (In Rus.)]

Жуковская 2000 - Жуковская Н. Л. Мир традиционной монгольской культуры. Серия: 
Российские труды по востоковедению. Т. 11. The Edwin Mellen Press. Lewiston-QueenstonLampeter, 2000. 310 c. [Zhukovskaya N. L. Mir traditsionnoy mongol'skoy kul'tury [The world of traditional Mongolian culture]. Series 'Studies of Russian Orientalists'. Vol. 11. New York: The Edwin Mellen Press, 2000. 310 p. (In Rus.)]

Михайлов 1962 - Михайлов Т. М. Бурятское шаманство и его пережитки. Иркутск[б.и.], 1962. 34 c. [Mikhailov T. M. Buryatskoe shamanstvo i ego perezhitki [Buryat shamanism and its vestiges]. Irkutsk, 1962. 34 p. (In Rus.)]

Михайлов 1980 - Михайлов Т. М. Из истории бурятского шаманизма (с древних времен до XVIII в.). Новосибирск: Наука, 1980. 320 c. [Mikhailov T. M. Iz istorii buryatskogo shamanizma (s drevnikh vremen do XVIII v.) [Excerpts from the history of Buryat shamanism: from the earliest times to the $18^{\text {th }}$ century]. Novosibirsk: Nauka, 1980. 320 p. (In Rus.)]

Михайлов 1987 - Михайлов Т. М. Бурятский шаманизм: история, структура и социальные функции. Новосибирск: Наука, 1987. 289 с. [Mikhailov T. M. Buryatskiy shamanizm: istoriya, struktura i sotsial'nye funktsii [Buryat shamanism: history, structure, and social functions]. Novosibirsk: Nauka, 1987. 289 p. (In Rus.)]

Хангалов 1958 - Хангалов М. Н. Собрание сочинений. Т. І. Улан-Удэ: Бур. кн. изд-во, 1958. 551 c. [Khangalov M. N. Sobranie sochineniy [Collected works]. Vol. 1. Ulan-Ude: Bur. Book Publ., 1958. 551 p. (In Rus.)]

Хангалов 1959 - Хангалов М. Н. Собрание сочинений. Т. II. Улан-Удэ: Бур. Книжное изд-во, 1959. 444 с. [Khangalov M. N. Sobranie sochineniy [Collected works]. Vol. 2. Ulan-Ude: Bur. Book Publ., 1959. 444 p. (In Rus.)]

Хангалов 1960 - Хангалов М. Н. Собрание сочинений. Т. III. Улан-Удэ: Бур. Книжное изд-во, 1960. 421 с. [Khangalov M. N.
Sobranie sochineniy [Collected works]. Vol. 3. Ulan-Ude: Bur. Book Publ., 1960. 421 p. (In Rus.)]

Харитонова 2006 - Харитонова В. И. Феникс из пепла? Сибирский шаманизм на рубеже тысячелетий. М.: Наука, 2006. 372 с. [Kharitonova V. I. Feniks iz pepla? Sibirskiy shamanizm na rubezhe tysyacheletiy [A Phoenix from ashes? Siberian shamanism at the turn of Millennium]. Moscow: Nauka, 2006. 372 p. (In Rus.)]

Цыбикжапова 1998 - Цыбикжапова E.-X. Космическая эволюция в героическом эпосе «Гэсэр». Улан-Удэ, 1998. 98 c. [Tsybikzhapova E.Kh. Kosmicheskaya evolyutsiya v geroicheskom epose "Geser» [Cosmic evolution as depicted in the Epic of Gesar]. Ulan-Ude, 1998. 98 p. (In Rus.)]

Balzer 1999 - Balzer, M. M. Shamans in All Guises: Exploring Cultural Repression and Resilience in Siberia. Curare: Zeitschrift für Ethnomedizin. Vol. 22. No. 2. 1999. Pp. 129134. (In Eng.)

Fridman 2004 - Fridman. Neumann E. J. Sacred Geography: Shamanism among the Buddhist Peoples of Russia. Bibliotheca Shamanistica. Vol. 12. Budapest: Akadémiai Kiado, 2004. 324 p. (In Eng.)

Humphrey 1998 - Humphrey, C. Marx Went Away - But Karl Stayed Behind. Update edition of Karl Marx Collective: Economy, Society and Religion in a Siberian Collective Farm. Ann Arbor: The University of Michigan Press, 1998. 599 p. (In Eng.)

Stepanova 1998 - Nadia Stepanova. L'Invocatrice degli Dei. Storie di vita di una Sciemana Buriata. Raccontata C. D'Arista [The God whisperer. Life story of a Buryat shaman. Narrated by C. D’Arista]. Milano, 1998. 193 p. (In Ital.)

Zhukovskaya 2009 - Zhukovskaya N. Heritage versus Big Business: Lessons from the YUKOS Affair. Inner Asia. Vol. 11. No. 1. 2009. Pp. 157-167. (In Eng.) 
UDC 39

\title{
Male and Female Shamans of Buryatia: Their Mystical Experiences and the Author's Field Research. Part One
}

\author{
Natalia L. Zhukovskaya ${ }^{1}$
}

${ }^{1}$ Ph.D. in History (Doct. of Historical Sc.), Head of Center for Asian and Pacific Studies, MikloukhoMaclay Institute of Ethnology and Anthropology of the RAS (32a, Leninsky prospect, Moscow, 119991, Russian Federation). ORCID: 0000-0001-5415-9875. E-mail: n-zhuk@yandex.ru

\begin{abstract}
Goals: Proceeding from multi-year field research data, the paper attempts to review some trends in the development of Buryatia's contemporary shamanism.

Methods: The work applies historical-comparative and comparative-contrastive research methods; a variety of field ethnographic research methods were used to collect corresponding analytical materials.

Results: The study provides an overview of current shamanistic practices in Buryatia. It is noteworthy that the new generation of shamans are university-educated individuals with experience in different specialities. Thus, the 'shamanistic intelligentsia' has taken shape. Their practices include not only traditional rites but also public conversations in the media aimed to facilitate the promotion of shamanistic beliefs and world outlooks. They write books, appear in documentary films, leave their ancestral lands for different Russian and foreign cities to perform their practices there - which has been frown upon in classical shamanism. The emergence of associations and alliances of shamans have resulted in that nowadays they engage in publishing and teaching (educational) activities. The new challenges required that personalities of traditional shamans change accordingly, and the new generation of in-demand shamans do possess such personal qualities.

The article comprises two parts. Part One generally characterizes the topic and depicts portrayals of three female shamans - representatives of the mentioned 'shamanistic intelligentsia', namely: Nadezhda Stepanova, Yeshir-Khorlo Tsybikzhapova, and Vera Taglasova. Their shamanistic evolutions are traditional enough and have included certain stages, such as shamanistic illness and shamanistic roots (even in cases of mixed parentage). At the same time, all the mentioned presentday female shamans of Buryatia have university degrees (in the humanities and culture), maintain close relations with academic circles, stay at the forefront of public life, being activists of shamanistic associations and regularly promoting corresponding beliefs and representations.

Part Two examines places of shamans and their associations in the new Russia. The paper shows that the newly emerged shamanistic organizations seek to keep performing their practices in changing environments when, acting as an official, shamans can register their sacred places as specially protected territories. On the other hand, another challenge of theirs is to protect the public from pseudo-shamans that have significantly increased in numbers recently. This part also contains sections to deal with the issues, such as 'shamans and scientists', 'shamans and ecology'. Both the parts of the article to be published in two consecutive issues of the journal shall be supplemented with complete references.
\end{abstract}

Keywords: Buryatia, shamanism, field research, shamans, new generation, shamanistic intelligentsia, shamanistic organizations, N. Stepanova, Ye.-Kh. Tsybikzhapova, V. Taglasova 